\title{
Improving Students' Reading Comprehension Through Request (Reciprocal Question) Strategy for Indonesian Junior High School
}

\author{
Rida Fahas ${ }^{1}$ \\ ${ }^{1}$ Corresponding Author, English Department, Universitas PGRI Madiun, Madiun, Indonesia \\ rida.fahas@unipma.ac.id
}

Received: December 31, $2020 \quad$ Accepted: January 18, $2020 \quad$ Published: January 22,, 2021

\begin{abstract}
Reading is an important skill in English language learning process. That is why a teacher must has an effective strategy in teaching reading. This study aims to improve the reading comprehension of eight grade students at Junior High School at Kedunggalar, Ngawi, East Java, Indonesia through Request (Reciprocal Question). To support the improvement, the writer uses Classroom Action Research (CAR) as the strategy of the study. There are two cycles and each cycle contained of four phases, namely planning, acting, observing and reflecting. The subjects of the study were 31 students of class VIII B of SMPN 2 Kedunggalar. The qualitative data were gotten by doing observatio. While the quantitative data were from the students' reading comprehension score of the pretest and post-test, then they were investigated descriptively. The students have to reach four indicators namely understanding of content, generic structure, languages feature and purpose of recount text. Applied request strategy improved the students reading skill. The enrichment supported them comprehending the texts. The improvement was supported by the compare of the studentse mean score from the pre-test, post-test 1 and post-test 2 with percentage students passed KKM, 33 percentage $0 \%, 41$ percentage $9,7 \%$ and $7796,8 \%$. Their participation in the reading class also improved. In addition, the students developed more active and they liked the process of teaching and learning reading.
\end{abstract}

Keywords: Classroom Action Research; Reading Skill; Request Strategy

To cite this article: Fahas, R. (2021). Improving the students' reading comprehension through request (reciprocal question) strategy for Indonesian junior high school. SALEE: Study of Applied Linguistics and English Education, 2(01). https://doi.org/10.35961/salee.v2i01.217

DOI: $10.35961 /$ salee.v2i01.217 


\section{Introduction}

Reading is an important skill in English language learning process. That is why a teacher must has an effective strategy in teaching reading. According to Harmer (2007) reading is beneficial for language acquisition. The students will understand what they read, the more they read, the better they get it. According to Grellet (2004) reading is a continual process of guessing and what one brings to the next is often more important than what one finds in it. In reading, the students should be taught to use what they know to understand unknown elements, whether these are ideas or simple words. Mikulecky (2011) states that reading is complex conscious and unconscious mental process in which the readers uses a variety of strategies to reconstruct the meaning that the author is assumed to have intended, based on data from the text and from the readeres prior knowledge.

Reading comprehension makes turn taking between teacher and students of discuss material in class, so students get feedback from teacher. Klinger et al (2007) states that "reading comprehension is the process of constructing meaning by coordinating a number of complex processes that include word reading,word and world knowledge and fluency" . Brown (2000) also states that reading comprehension is primarily a matter of developing appropriate, efficient comprehension strategies. Some strategies are related to bottom-up procedures, and other enchances the top-down processes. According to Khoiriyah (2010:1) reading comprehension is the act of combining information in a passage with prior knowledge in order to construct meaning. In addition, reading comprehension can be defined as a thinking process through which readers become aware of an idea, understand it in terms of their experiential background, and interpret it in relation to their own needs and purpose.

Talking about reading activities, there are some strategies that can be used by the English teachers. Absolutely, every teacher should choose the appropriate one to reach their goals. For example in Indonesia, it is known that most of the classes are big. These classes can consist of 32 up to 45 students. Consequently, it is hard for the teacher to make the contact to the students directly, moreover students at the back row. The teacher will be difficult to control every student one by one. On the other side, it is also difficult for the students to ask for and receive individual attention.

The teachers must consider a strategy that suitable for teaching reading in order to make the learning process becomes effective. The strategy its self should be adjusted with the condition of the class and ability of the students. Because every class has its condition its self, it also will determine the suitable strategy its self. There are some strategies in teaching reading comprehension like PQRST(Preview, Question, Read, Summarize and Test), SQ3R (Survey, Question , Read Recite Review ), and QAR ( QuestionAnswer Relationship), Request (Reading Question). The teacher must be able to make variations and choose the suitable strategy in order to attract " interesting in reading. The researcher chooses Request (Reciprocal Question) in research because this strategy can improve students ability and skill of reading. On other, the students can get feedback from teacher.

As stated by Klinger, Vaughn, and Boardman (2001), the reciprocal teaching startegy is an instruction that is developed to help students who can decode the language but have difficulty in comprehending the text. Foster and Rotoloni (2008) also define reciprocal teaching as a teaching method that gives students model and prompts students thinking process on how to share their learning experience. In addition, Brown in Klinger, Vaughn, 
and Boardman (2001) says that reciprocal teaching is based on the Vygotsky's theory of ZPD (Zone of Proximal Development) which focuses on improving students' skills and knowledge with guidance which is provided through interactions in the class.

According to Manzo (2008) Reciprocal-Questioning (ReQuest) procedure is a reading strategy that gives students the opportunity to ask questions of the teacher. The purpose of ReQuest is to encourage students to formulate their own questions about the material they are reading and to develop appropriate questioning behavior. In doing so, students improve their reading comprehension skills, set purposes for reading, and develop an active, inquiring attitude toward reading. This strategy can be used with narrative and expository text. According to Richardson Reciprocal-Questioning (ReQuest) is a questioning strategy that encourages students to ask informed questions. This procedure seems to work especially well in a remedial situation or with poor readers. The key to this strategy is that is requires students to "open up" their thinking to question and think critically. With this strategy, the teacher and students first read silently a selected portion of the text (usually one or two paragraph). The students then ask the teacher question about what they read. They teacher must keep the book closed during this phase. When the students exhaust their question, the teacher begin asking question. During this phase, the students must also keep their book closed. The activity can be repeated with other paragraphs as time allows. The teacher then sets purposes for reading the remainder of the lesson, referring to the questions asked and information received during the Request.

In the Request procedure condition the instructor gave the subjects part of the text to be read and asked them to try to come up with questions about the subject which they would like to have answered in the text. Whenever possible tentative answers were given to the questions by volunter students, and as the activity developed the instructor inserted her own questions in order to help students ask more questions leading to higher levels of comprehension. In the condition where the two activities were worked together, the request procedure was added to the possible sentences procedure for the same text.

Based on the writer experience and after interview with the English teacher in class, there are have reason problem in process teaching learning in class English reading. The students are difficult to comprehend the text, it makes them confused. They sometimes can ${ }^{\text {ee }}$ find the ideas of whole the text. Besides that, teacher only ask the meaning sentence from text without give explanation, it makes students bored and confused. And sometimes students are noisy in the teaching learning process with their friend. And the situation in class become crowded and less attention.

The writer choose SMPN 2 Kedunggalar because the school was close to home, had studied at the school and the school is the best in the area. And choose class VIII B because in there only have 2 class there are VIII A and VIII B. In reading recount texts, the eighth grade students are expected to be able to comprehend a recount text.The students were able to identifying the purpose in reading, be able to identifying the main idea, be able to identifying detail information of recount text. A lot of students get a good scoring, mostly they are get score under 75, it of minimum standard criteria (KKM) in school.

Based on the writer's observation above, it's known that teachers' technique in teaching reading is one of the students' problems in learning English. The writer wants to solve the problem by using Request strategy. Request strategy requires that the learner or students pay attention what they read and can comprehend from the text. The students can be active and 
be creative in reading class to reach reading comprehension. The students can ask about the something what she or he did not know about the text for the teacher and give turn taking both.

It can be summarized that Request Strategy can help students to comprehend with the text have been read so they can know how found main idea, can identifies generic structure and can analyze language feature. Then the writer conducts the objective of this research as to describe ways of any Improvement of the students' reading comprehension through request strategy for eight grade students of SMPN 2 Kedunggalar 2019/2020.

\section{Literature Review}

Number of prior studies pertaining to reading strategy have been documented in Indonesian context. The first is carried out by Retno (2015). Her researcher aims at improving the reading comprehension of grade X IIS 1 at SMAN 1 Kasihan in the academic year 2014/2015. The study is action research. It was done in collaboration with the students, the English teacher, and the researchers' colleague. The steps of research were planning, action and observation and reflection. The subjects of the research were 32 students of grade X IIS 1 at SMAN 1 Kasihan. The research was carried out in two cycles and the data were collected both qualitatively and quantitatively. The result of the research shows that using reciprocal teaching improves studentse ${ }^{\text {ec }}$ reading comprehension. The improvement was also proved by students' mean score in the post-test which was higher than in the pre-test.

The second previous research is from Elsi (2013). The writer found that there is any significant different of Reciprocal Questioning (Request) procedure toward reading comprehension of second year students at Madrasah Aliyah Diniyah Puteri Pekanbaru, where T show 4053 at significant level 5\% it show 2.01, and at the level of $1 \%$ it shows 2.68.

The third previous research is conducted by Dian (2013). The research results show that reading comprehension of most students improved after the reciprocal teaching was conducted. First, students made improvement of some aspect such as predicting the content of the text, finding details information or important information of a text, guessing meaning of the difficult word, finding main idea of paragraph, made conclusion or summary of a text. Second, students were enthusiastic in the reading activity. The activity motivated them to learn. Third, students became more confident in doing the reading activity and reporting their work. Fourth, the interaction among the students and between the students and teacher improved after the implementation of the group discussion and class discussion. The last, students $^{\text {ee }}$ reading comprehension improved. It was indicated of the increase of the mean of students $^{\text {ee }}$ reading comprehension score in pre-test and post-test (4.63 to 6.30).

This writer was designed to improve the students' reading comprehension by using Request strategy. Request strategy requires that the learner or students pay attention what they read and can be comprehend of text. They are can be active and be creative in reading class to reach the goal because they are can ask about the something what didn ${ }^{\text {ee }}$ know about text to teacher. Request strategy has the advantage can help respond to reading a specific text, can help getting new information, to reach students potential in reading passage and to provide feedback question ${ }^{\text {ee }}$ s student. 


\subsection{Request Strategy}

According to Williams (2002) request strategy is strategy to helps the students to learn how to create effective question as models a questioning strategy. In addition, Murray (2002) states that request strategy is a strategy ask for the teacher to model good questioning behavior, to provide feedback to students about their question and to help students establish purpose independently completing in a reading.

According to Manzo (2008) there are steps request strategy :

a. Silent reading: the teacher and the students read the section of text independently and silently.

b. Students questioning: the teacher models how the answer question and the shape the students question, students ask question the teacher answer them.

c. Teacher questioning: the teacher models how to ask appropriate questions.

d. Integration of the text: repeat the procedure with the next sections of the text.

e. Predictive questioning: after students have read enough of the passage that they can make prediction about the rest of the text, stop and ask them to make prediction.

f. Reading: read to the end of the text verify prediction

From the explanation about the procedure of request strategy above, it is according procedure from Manzo (2008) because the procedure help students ask important questions and can be used in difficult or important parts of text, soothe students can be easy to understand and comprehend the text because the students give chance to question and the teacher answer and students can understand something that they haven ${ }^{\text {ee }}$ understood yet.

\section{Method}

In this research, the researcher used form of classroom action research (CAR). Classroom action research is a kind of research that is conducted in the classroom by teacher. According to Mulyasa (2009) classroom action research is a kind of research that has reemerged as a popular way of involving practitioner, both teacher and supervisor, so that they better understand their work. Therefore classroom action research is a form of research that is conducted by practitioners to improve practices in educational setting.

According to Kemmis and Mc.Taggart (2005) there are four components in one cycle for doing classroom action research. It consists of (1) planning, (2) acting, (3) observing, (4) reflecting.

\section{a. Planning}

Planning as the first step of research procedure is done to give solution for the indentified problem. It is a plan to conduct to treatment. In order to improve students ${ }^{\text {ee }}$ understand on reading skills.

b. Acting

After planning the concept, the researcher carried out the treatment referring to the plan has been mad. The researcher conducted a pre-test before applying the treatment.

\section{c. Observing}


Observation is the activity of observing the data collected in order to know what extent the action activities has reached the objectives of the research. In this step, the researcher identified and analyzed the data collected during treatment.

\section{d. Reflecting}

Reflection is the activity of evaluating critically the progress or change of the students. In this step, the researcher reflected on evaluated and described the effects of the implementation Request strategy in teaching and learning reading skill.

\subsection{Respondents}

This research was done to the students of SMPN 2 Kedunggalar Ngawi in the academic year 2019/2020. The researcher did the research in the class VIII B which contains 31 students. In the classroom there were 20 males and 11 females. In this research, the researcher chose randomly the sample of the research using lottery. The steps are as follows: (1) listing students' names in each small paper; (2) scrolling the paper; (3) putting the paper into bottle, and (4) choosing one paper to determine the name.

\subsection{Instruments}

In this research, the researcher applied pre-test and post-test. The test is given question. The pre-test was given before the researcher applied the treatment. The treatment is about reading recount text using request strategy. The researcher gives the treatment twice meeting. Then the last meeting the researcher give the post-test to students to know students ${ }^{\text {ee }}$ achievement in reading recount text using request strategy.

\subsection{Procedures in Collecting Data}

\subsubsection{Observation}

The observation was done to identify the students' attitude toward English lesson and class situation during teaching learning process using request strategy. The researcher prepare observation consist of the students attitude, collaboration and communication with other group in learning process.

\subsubsection{Test}

Reading comprehension test were conducted to gain the information about how successful the actions improve the students ${ }^{\text {ee }}$ reading comprehension. It consisted of two test which were administered before and after the action. The namely the pre-test was conducted before the action. And the other namely post-test was conducted after the action. Besides the reading comprehension test, the writer also administered the assessment task. The assessment task were used to gain the information about the strengths and weakness of the actions and the improvement students reading comprehension in teaching learning.

\subsection{Data Analysis}

This writer the data were collected by quantitative and qualitative data. The quantitative data were gained through reading comprehension test both the pre-test and post-test. 
Quantitative data that focuses n numbers and mathematical calculation and can be calculated and computed. In quantitative data analysis used table for values students from value pre-test and post-test.

The qualitative data were gained from observation this used describe data which was not opened to being counted or measure in an objective way and was therefore subjective. Qualitative data is a data concerned with descriptions, which can be observed but cannot be computed. In this, the value students are described using words. For described value students from pre-test and pro-test as an increase in value.

\section{Finding and Discussion}

The research consisted of two cycles with a test after each cycle was done. The researcher conducted the test to know the condition of students ${ }^{\text {ee }}$ reading skill after implementing the action use Request strategy. The implementation of the research was conducted collaboratively with the English teacher of SMPN 2 Kedunggalar. This research began to give a pre-test.

\subsection{Pre-Test}

The researcher give pre-test to students for measure the data of the students ${ }^{\text {ee }}$ reading skill in recount text before the researcher gives treatment in the class.

Table. 1 The Students Pre- Test Score

\begin{tabular}{lllllll}
\hline No. & Purpose & $\begin{array}{l}\text { Generic } \\
\text { structure }\end{array}$ & $\begin{array}{l}\text { Language } \\
\text { feature }\end{array}$ & Understanding & $\begin{array}{l}\text { Total } \\
\text { Score } \\
\text { Indicator }\end{array}$ & Value \\
\hline 1 & 2 & 0 & 1 & 1 & 4 & 20 \\
\hline 2 & 2 & 2 & 1 & 4 & 9 & 45 \\
\hline 3 & 2 & 1 & 1 & 2 & 6 & 30 \\
\hline 4 & 3 & 3 & 0 & 1 & 7 & 35 \\
\hline 5 & 2 & 2 & 1 & 3 & 8 & 40 \\
\hline 6 & 3 & 1 & 1 & 1 & 6 & 30 \\
\hline 7 & 2 & 2 & 1 & 3 & 8 & 40 \\
\hline 8 & 2 & 1 & 1 & 1 & 5 & 25 \\
\hline 9 & 1 & 3 & 1 & 2 & 7 & 35 \\
\hline 10 & 1 & 3 & 1 & 2 & 7 & 30 \\
\hline 11 & 2 & 2 & 1 & 4 & 9 & 45 \\
\hline 12 & 2 & 2 & 1 & 3 & 8 & 35 \\
\hline 13 & 2 & 0 & 1 & 2 & 5 & 25 \\
\hline 14 & 2 & 2 & 1 & 1 & 6 & 30 \\
\hline 15 & 2 & 1 & 1 & 1 & 5 & 25 \\
\hline 16 & 2 & 2 & 1 & 2 & 7 & 35 \\
\hline 17 & 2 & 2 & 1 & 3 & 8 & 40 \\
\hline 18 & 2 & 2 & 1 & 3 & 8 & 45 \\
\hline 19 & 2 & 1 & 1 & 1 & 5 & 25 \\
\hline 20 & 1 & 3 & 1 & 1 & 6 & 30 \\
\hline 21 & 2 & 0 & 0 & 2 & 4 & 20 \\
\hline & & & & & & \\
\hline
\end{tabular}




\begin{tabular}{lllllll}
\hline 22 & 2 & 2 & 1 & 3 & 8 & 35 \\
\hline 23 & 2 & 2 & 1 & 3 & 8 & 40 \\
\hline 24 & 2 & 3 & 0 & 2 & 7 & 35 \\
\hline 25 & 3 & 2 & 1 & 2 & 8 & 40 \\
\hline 26 & 2 & 2 & 1 & 4 & 9 & 45 \\
\hline 27 & 2 & 1 & 1 & 1 & 5 & 25 \\
\hline 28 & 3 & 0 & 1 & 1 & 5 & 25 \\
\hline 29 & 2 & 1 & 1 & 1 & 5 & 25 \\
\hline 30 & 2 & 2 & 1 & 1 & 6 & 30 \\
\hline 31 & 1 & 2 & 2 & 1 & 6 & 1015 \\
\hline Total & 62 & 52 & 29 & 64 & 207 & 33 \\
\hline Mean & 2 & 2 & 1 & 2 & 7 & \\
\hline
\end{tabular}

According to table above, the researcher can conclusion that mean the score indicator from purpose, generic structure, language feature and understanding is two for purpose, two for generic structure, one language feature and two for understanding. All students are lack of skills in all of aspect four indicator. The reason behind this is that they got confused on meaning the words or lack of vocabulary storages and less understanding about generic structure, purpose, language features of recount text.

\subsection{Cycle 1}

The researcher did several steps in conducting a classroom action research. In cycle 1, the researcher did the two meeting which are conducted in 15 to 16 July 2019. Before implementing the action, the researcher planned everything related to the action in first cycle. They were as follows preparing materials for the teaching, making lesson plan, and designing the steps in doing the action, preparing sheets of classroom observation, preparing camera to make documentations, and preparing post-test cycle 1.

The researcher analyzed the result in cycle one and madethe reflection to evaluate the teaching learning process. Observation result showed that there were some improvements achieved by the students after doing the action. The result of students ${ }^{\text {ee }}$ reading skill in cycle 1 showed in the following table:

Table. 2 The Students Post Test 1 Score

\begin{tabular}{lllllll}
\hline No. & Purpose & $\begin{array}{l}\text { Generic } \\
\text { structure }\end{array}$ & $\begin{array}{l}\text { Language } \\
\text { feature }\end{array}$ & Understanding & $\begin{array}{l}\text { Total } \\
\text { Score } \\
\text { Indicator }\end{array}$ & Value \\
\hline 1 & 2 & 2 & 1 & 4 & 9 & 45 \\
\hline 2 & 3 & 1 & 1 & 2 & 7 & 35 \\
\hline 3 & 2 & 2 & 1 & 3 & 8 & 40 \\
\hline 4 & 1 & 1 & 1 & 3 & 6 & 30 \\
\hline 5 & 4 & 4 & 4 & 3 & 15 & 75 \\
\hline 6 & 0 & 1 & 2 & 3 & 6 & 30 \\
\hline 7 & 2 & 2 & 1 & 3 & 8 & 40 \\
\hline 8 & 2 & 2 & 1 & 3 & 8 & 40 \\
\hline 9 & 2 & 2 & 1 & 3 & 8 & 40 \\
\hline
\end{tabular}




\begin{tabular}{|c|c|c|c|c|c|c|}
\hline 10 & 3 & 4 & 4 & 4 & 15 & 75 \\
\hline 11 & 3 & 1 & 1 & 1 & 6 & 30 \\
\hline 12 & 2 & 2 & 1 & 3 & 8 & 40 \\
\hline 13 & 1 & 2 & 1 & 3 & 7 & 35 \\
\hline 14 & 3 & 2 & 0 & 3 & 8 & 40 \\
\hline 15 & 1 & 2 & 1 & 4 & 8 & 40 \\
\hline 16 & 2 & 3 & 1 & 2 & 8 & 40 \\
\hline 17 & 2 & 3 & 1 & 3 & 8 & 40 \\
\hline 18 & 3 & 1 & 2 & 2 & 8 & 40 \\
\hline 19 & 2 & 2 & 1 & 3 & 8 & 40 \\
\hline 20 & 2 & 2 & 1 & 3 & 8 & 40 \\
\hline 21 & 2 & 1 & 1 & 3 & 7 & 35 \\
\hline 22 & 1 & 1 & 1 & 4 & 7 & 35 \\
\hline 23 & 3 & 1 & 1 & 2 & 7 & 35 \\
\hline 24 & 3 & 3 & 4 & 5 & 15 & 75 \\
\hline 25 & 4 & 1 & 1 & 1 & 7 & 35 \\
\hline 26 & 2 & 1 & 2 & 2 & 9 & 35 \\
\hline 27 & 1 & 1 & 2 & 2 & 6 & 30 \\
\hline 28 & 1 & 2 & 0 & 4 & 7 & 35 \\
\hline 29 & 2 & 3 & 1 & 2 & 8 & 40 \\
\hline 30 & 3 & 2 & 1 & 4 & 9 & 45 \\
\hline 31 & 3 & 2 & 1 & 2 & 8 & 40 \\
\hline Total & 67 & 59 & 42 & 89 & 257 & 1280 \\
\hline Mean & 2 & 2 & 1 & 3 & 8 & 41 \\
\hline
\end{tabular}

Based on the score above, the researcher can compare between mean score of pretest and post-test 1 . It could be seen from this studentsmean score table

Table. 3 Comparing mean score of pre-test, post-test 1

\begin{tabular}{|c|c|c|c|c|}
\hline No. & Mean Score & & Percentage pre-test and post-test 1 & \\
\hline 1 & Pre-test & 33 & Number of students passed KKM & $0 \%$ \\
\hline \multirow{3}{*}{2} & \multirow{3}{*}{ Post-test 1} & \multirow{3}{*}{41} & $\begin{array}{l}\text { Number of students did not passed } \\
\text { KKM }\end{array}$ & $100 \%$ \\
\hline & & & Number of students passed KKM & $9,7 \%$ \\
\hline & & & $\begin{array}{l}\text { Number of students did not passed } \\
\text { KKM }\end{array}$ & $90,3 \%$ \\
\hline
\end{tabular}

Their score of post test still low even there was improvement. While criteria of success in this research the researcher make target $80 \%$ from students reach minimum standard criteria (KKM) was 75 . It means that the students passed the KKM must be 30 students.

\subsection{Cycle 2}

The researcher had reached good enough result in cycle 1. To make sure the improvement of students ${ }^{\text {ee }}$ reading skill through Request strategy, the research continued to 
cycle 2 . In cycle 2 , the researcher did one meeting which are conducted in Wednesday, 17 July 2019.

Based on the result of cycle 1, the researcher realized that there were improvements of the students ${ }^{\text {ee }}$ reading skill, but still found some problems that the students comprehend a text. To solve the weakness emerged in cycle 1 , the researcher made a revised plan to teach reading in cycle 2 based on the observation and reflection from teaching learning process in cycle 1 . The researcher reviewed the material in the first cycle by explain about recount text: the purpose of recount text, the generic structure of recount text, and the language feature of recount text. It aimed to remain students to the material. And add knowledge about recount text.

In the cycle 2 , the researcher found some improvements. The students were more motivated and interested in teaching learning process. The students were more enthusiastic in joining the class with Request strategy. The students got better understanding about goal, generic structure, and language feature in recount text. They got better understanding about the materials. To show more details about improvement of the students ${ }^{\text {ee }}$ reading comprehension score, can be showed from table 5:

Table. 5 The Students Post Test 2 Score

\begin{tabular}{lllllll}
\hline No. & Purpose & $\begin{array}{l}\text { Generic } \\
\text { structure }\end{array}$ & $\begin{array}{l}\text { Language } \\
\text { feature }\end{array}$ & Understanding & $\begin{array}{l}\text { Total } \\
\text { Score } \\
\text { Indicator }\end{array}$ & Value \\
\hline 1 & 5 & 1 & 4 & 5 & 15 & 75 \\
\hline 2 & 5 & 2 & 4 & 5 & 16 & 80 \\
\hline 3 & 5 & 2 & 4 & 5 & 16 & 80 \\
\hline 4 & 4 & 4 & 3 & 4 & 15 & 75 \\
\hline 5 & 5 & 2 & 4 & 5 & 16 & 80 \\
\hline 6 & 4 & 4 & 3 & 5 & 16 & 80 \\
\hline 7 & 5 & 2 & 4 & 5 & 16 & 80 \\
\hline 8 & 5 & 2 & 4 & 5 & 16 & 80 \\
\hline 9 & 5 & 3 & 3 & 5 & 16 & 80 \\
\hline 10 & 5 & 1 & 4 & 5 & 15 & 75 \\
\hline 11 & 5 & 2 & 4 & 5 & 16 & 75 \\
\hline 12 & 5 & 2 & 3 & 5 & 15 & 75 \\
\hline 13 & 4 & 1 & 2 & 5 & 12 & 60 \\
\hline 14 & 5 & 1 & 4 & 5 & 15 & 75 \\
\hline 15 & 5 & 3 & 2 & 5 & 15 & 75 \\
\hline 16 & 4 & 3 & 3 & 5 & 15 & 75 \\
\hline 17 & 5 & 2 & 4 & 4 & 15 & 75 \\
\hline 18 & 5 & 3 & 4 & 5 & 17 & 85 \\
\hline 19 & 5 & 1 & 4 & 5 & 15 & 75 \\
\hline 20 & 5 & 1 & 4 & 5 & 15 & 75 \\
\hline 21 & 4 & 3 & 3 & 5 & 15 & 75 \\
\hline 22 & 4 & 3 & 3 & 5 & 15 & 95 \\
\hline 23 & 5 & 4 & 5 & 5 & 19 & \\
\hline 24 & 5 & 4 & 2 & 5 & & 70 \\
\hline & & & & & 5 & \\
\hline
\end{tabular}




\begin{tabular}{lllllll}
\hline 25 & 4 & 3 & 5 & 5 & 17 & 85 \\
\hline 26 & 4 & 3 & 3 & 5 & 15 & 75 \\
\hline 27 & 3 & 4 & 4 & 4 & 15 & 75 \\
\hline 28 & 4 & 3 & 3 & 5 & 15 & 75 \\
\hline 29 & 5 & 1 & 4 & 5 & 15 & 75 \\
\hline 30 & 5 & 2 & 4 & 5 & 15 & 75 \\
\hline 31 & 4 & 3 & 3 & 3 & 13 & 65 \\
\hline Total & 143 & 75 & 110 & 149 & 477 & 2400 \\
\hline Mean & 5 & 2 & 4 & 5 & 15 & 77 \\
\hline
\end{tabular}

Based on the score above, the researcher can compare between score of post-test 1 and post-test 2 . It could be seen from these students.

Table 6 Comparing mean score of pre-test, post-test 1 and post-test 2 mean score table:

\begin{tabular}{llllr}
\hline No. & Mean Score & & Percentage pre-test and post-test 1 & \\
\hline 1 & Pre-test & 33 & Number of students passed KKM & $0 \%$ \\
\hline \multirow{3}{*}{2} & & Number of students did not passed & $100 \%$ \\
& \multirow{3}{*}{ Post-test 1 } & \multirow{2}{*}{41} & KKM & $9,7 \%$ \\
\cline { 3 - 4 } & & Number of students passed KKM & Number of students did not passed \\
& & KKM & $90,3 \%$ \\
\hline 3 & Post-test 2 & 77 & Number of students passed KKM & $96,8 \%$ \\
\hline & & Number of students did not passed & $3,2 \%$ \\
\hline
\end{tabular}

Based on the table above, it can be summarized that students's reading comprehension skill improved. From the mean score pre-test was 33 increased to 41 in post-test 1 percentage $9,7 \%$ and it became 77 in post-test 2 percentage $96,8 \%$. And show that the number of students passed KKM in pre-test was there is no, post-test 1 was 3 students and post-test 2 was 30 students. The results of the test showed the improvement of the students's reading comprehension skill in recount text. It could be seen from the mean score between post-test 1 and posttest 2 where the mean score in post-test 2 was higher than post-test 1 . It almost can be said that their scores was improve. It was happened because the students had already had good background knowledge related to the topic which the researcher gave in the post-test 2. Furthermore, the implementation of Request strategy helped the students in reading recount text.

Based on the data which gathered from the pre-test and post-test the researcher concluded several findings that answer the problem statement of the research as stated in chapter one that is the achievement of the students. In this process, the researcher identified some factors causing the reading ability of the students VIII B was low. There are some difficulties understanding the text, didn't like reading because didn't understand the meaning of text, lazy to open dictionary. They also had low motivation in English lesson, especially 
in reading a text. The teacher does not push skill for reading in the classroom. Therefore, the students lack of time to reading in class.

Based on the score of pre-test, the researcher can be summarized that there are many students that the score was low from 31 students there are no students passed KKM. After know students ${ }^{\text {ee }}$ score the researcher start to arrange several steps in cycle 1 . This research held during the two meeting. The first meeting the researcher started teaching using request strategy. The students were very enthusiastic and very happy. Then the researcher explained about recount text. After that the researcher asked to the students to discuss about structure of recount text. The second meeting the researcher reviewed the material and asked the students to try read text recount in paper. They read text one by one alternately. They were very active. Then, the researcher gave post-test 1 to know the students ${ }^{\text {ee }}$ reading comprehend after they got treatment. Based on the score in post-test 1, it could be seen there are any improvement but in this cycle the researcher has target $75 \%$ from 31 students reach minimum standard criteria (KKM). It means that 30 students must be passed KKM. So the researcher held cycle 2.

In the cycle 2 the researcher did one meeting. The meeting the researcher started to give some examples of recount text then they are to discuss structure of recount text with seatmate. After that give question in paper for to do. Then, the researcher gave post-test 2 to know the students ${ }^{\text {ee }}$ reading score after the second cycle was applied. The students did the test seriously because they did not allow to cheat. The result of the test showed that any improvement of the students ${ }^{\text {ee }}$ reading skill in recount text. It could be seen from the mean score between posttest 1 and post-test 2 where the mean score in post-test 2 was higher than post-test. It means that reading strategy makes the students have better understanding about recount text.

\section{Conclusion}

Based on the result of research findings in the previous chapter, the researcher makes the conclusion about using Request strategy to teach the students reading skill at the Eight Grade of SMPN 2 Kedunggalar in the Academic Year of 2019/2020 as follows:

The students' ability in reading skill was still very less, this is known from mean score pre-test 33 from 31 students no one students did not pass from KKM 75 and the percentage is $0 \%$, this is because the students less understand in reading comprehension such as less understanding from content text, still don't understand about generic structure, language features, purpose and don't know the meaning of words. After the treatment has more progress, known from mean score first post-test 41 the students from 31 only 3 students passed KKM and percentage first post-test passed KKM is 9,7\%. The students still less in known language features this known from mean score per indicators show language features is low compared from known purpose, generic structure and understanding. After treatment in cycle two the students has more progress again is known from mean score 77, only one students did not passed KKM, then percentage the students passed KKM is 96,8\%. From mean score per indicators language features is low compared indicators another.

The eight grade students of SMPN 2 Kedunggalar still have many difficulties in meaning of words and did not understand content of text. The students less active in reading because the lazy to read did not known meaning of words and lazy to open the dictionary. But in each cycle has more progress in understanding purpose, language features, generics structure and 
understand of content text. It concluded that by using request strategy can improve ability English and very helpful for students especially in reading skill.

Based on this research, Request Strategy is effective to teach students' reading at eight grade of SMPN 2 Kedunggalar in the academic year 2019/2020. The researcher proposes the following suggestion for the teachers, this researcher can be improving English, especially for reading comprehension on Recount text. Then, it is hoped that this research can encourage them to consider a better way in teaching reading skill to improve the students ${ }^{\text {ee }}$ ability in reading skill. For Students, Request strategy expected can improving knowledge English reading comprehension. The students need motivation and apply interesting strategy in learn English reading. For the other researcher, the researcher discusses the effectiveness of using request strategy towards students reading skill at eight grade students. The researcher suggest to the other researcher to use request strategy in another grade in order to give progress in reading skill. For the institution of SMPN 2 Kedunggalar It is suggested to give adequate facilities for teaching and learning in class.

\section{References}

Ambarsiwi, Retno. (2015). Improving Students' Reading Comprehension of Grade X IIS 1 at SMAN 1 Kasihan in the Academic year of 2014/2015 Through The Use of Recprocal Teaching. Yogyakarta ; Skripsi, Universitas Negeri Yogyakarta.

Arikunto.(2006). Prosedur Penelitian Suatu Pendekatan Praktek. Jakarta:PT Rineka Cipta

Brown, Dauglas H.(2004).Language Assessment Principles and Classroom Practices. New York.Pearson Education.

Brown.(2001). Teaching by Principle:An Interactive Approach to Language Pedagogy .New York: Longman.

Derewianka.I,S.P.(2009).Teaching ESL/EFL Reading and Writing. NewYork: Routledge

Grellet. (2004). Developing reading skills. Sydney: Cambridge university press.

Khoiriyah (2010). Reading 1.Kediri: English Department Nusantara PGRI Kediri University Press.

Klingner,J.K., Vaughn, S. and Boardman, A. (2007). Teaching Reading Comprehension to Students with Learning Difficulties.New York: The Guilford Press.

Kung, F.W. (2017). Teaching second language reading comprehension: the effects of classroom materials and reading strategy use. Innovation in Language Learning and Teaching, 1-12.

Manzo, Anthony V \&Casela, Ula P.(2008). Teaching Children to be Literate: A Reflective Approach. New York: Holt, Rinehart and Winston, Inc.

Mikulecky,B.S.(2011).A short course in teaching reading:Practical technique for building reading power. New York: Pearson Longman 
Nation,I.S.P.(2009).Teaching ESL/EFL Reading and Writing.New York.Routledge

Nunan David.(2003).Language Teaching Methodology.London:Prentice Hall International

Pardiyono. (2007).Pasti Bisa!!.Teaching Gendre-Based Writing.Yogyakarta:C.V Andi Offset

Raudah, R. (2020). The Effectiveness of Quantum Learning Model toward Eight Grade Students' Reading Skills in SMP N 12 Bintan. SALEE: Study of Applied Linguistics and English Education, 1(02), 10-18.

Sugiyono.(2010). Metode Penelitian (Pendekatan Kuantitatif, Kualitatif, dan $R \& D$ ). Bandung: ALFABETA

Susanti, Elsi. (2013). The Effect of Using Request Procedure towards Reading Comprehension of the Second Year Students at MA Diniyah Puteri. Skripsi thesis, Universitas Islam Negeri Sultan Syarif Kasim Riau.

Utami, Dian.(2013). Using Reciprocal Teaching to Improve the Reading Comprehension of Grade VII Students of SMPN 13 Yogyakarta. Skripsi, Universitas Negeri Yogyakarta.

William.G and Fedricka L. Stoller.(2002). Teaching and Researching Reading. London: Pearson Education. 